\title{
Qassim Postgraduates Value Assimilation and the Role of Social Networking Sites in It
}

\author{
Hend Alsmadi \\ Principles of Education, Qassim University, Qassim, Saudi Arabia \\ Email: hendsmadi2@gmail.com
}

Received 7 April 2016; accepted 12 June 2016; published 15 June 2016

Copyright (C) 2016 by author and Scientific Research Publishing Inc.

This work is licensed under the Creative Commons Attribution International License (CC BY). http://creativecommons.org/licenses/by/4.0/

(c) (i) Open Access

\begin{abstract}
The study aimed at recognizing the degree of Qassim postgraduate's value assimilation and the role of electronic social networking in their assimilating from their point of view. Two tests are constructed. The first measures the degree of Qassim postgraduate students' value assimilation from their point of view; it consists of 46 items allocated to teaching and learning, social and moral values. The second measures the role of electronic social networking in their assimilation of the values; it consisted of 46 items. The sample included (730) students who were recruited in a simple random manner to participate in the study. Participants' value assimilation degree was moderate; the overall average scored (3.35); social networking role was moderate; also the overall average scored (3.63); the value of teaching and learning was the highest $(M=3.89)$, while social values scored the lowest $(M=3.21)$. No statistical differences at $(\alpha=0.05)$ attributed to gender were found. But differences were found attributed to the number of friends in favor of (more than 31 friends) in the social values and overall degree.
\end{abstract}

\section{Keywords}

Assimilation, Qassim Postgraduates, Social Networking Sites, Values

\section{Introduction}

The current time witnesses rapid changes and developments in technology, computers and mobiles dominate most owned machines by young people to keep in touch with each other mostly by social networks such as Facebook, Twitter, YouTube, MySpace, and WhatsApp. Social networks are used in sharing information, expressing and exchanging opinions and ideas, know others and attract large groups of the society, especially youths who are the hope of societies and its future, to form social networks. The role of social networks in forming attitudes, values, political and social awareness cannot be ignored; recent political and social events in the middle east region reveal a major role of social networks in spreading ideas, gaining crowd's sympathy and support in 
decision making [1]. In the west the case is more apparent.

As a result the social system changed due to the technological developments; in the values domain some values became neglected and others emerged; hence each community had its wide variety of coherent and sometimes divergent values. Values are of great importance to the individual and society, as they are considered the criteria or the test with which deeds are hindered valid or not, with which we distinguish bad from good; they are the reference in decision-making, and they combine religious and life matters, that is why they should be given most attention [2].

\subsection{Background}

\section{The Importance of Values}

The importance of values at the individual level as [3] stated; Values are considered guidelines of behavior and standards for judging individuals actions, it controls behaviors to bring about unity and consistency of all the individual actions; they help in predicting individuals actions in life events, for instance if an individual is being truthful, he is predicted to behave as such with himself and others; Values are responsible for the individual judgments about actions and events; they are general standards and they are agreed upon from all, hence who assimilates them becomes welcomed in the society.

As for values importance on the society level as [4] said "values exceeds cohesion, connection and strength of the society; maintain stability in the society and helps in confronting changes that occur; prevents from evil tendencies such as selfishness; provide the society with ways to deal with other societies, they determine objectives and justifications of its existence; they are considered a mean of judging the behavior of the individuals in the society, they set standards of actions and measures of assessment; are used in psychotherapy, if individuals are able to control themselves, they are also used in guidance, counseling and choosing different individuals for different professions.

Social Networking Sites (henceforth SNSS) Concept is correlated with values, and is defined as set of images and patterns of networking where topics and questions are sent, answers or responses on current topics may be sent also [5]. SNSS are also defined as a system of networks based on participant building of a site and involve other participants who share similar interests and activities in [6]. For [7] SNSS are the sites that facilitate building virtual societies and sharing a content developed and controlled by a user.

SNSS role in peoples life is apparent in maintaining relations with friends, enhance new friendships and meet new people. SNSS allow individuals to establish and maintain effective relations with a wide group of people; because friendship satisfies a psychological need that motivate them to communicate [8]. Most important factors of involvement in SNSS for [9] is that it allows individuals to present themselves good, post pictures that are satisfying, it also allows them to talk about their interests and favored topics.

Entertainment is considered a leading motive to attract individuals to participate in SNSS, by games or relaxing and social interaction with others [10]. SNSS are considered a mean of political, cultural and religious communication. It has also become a means of advocacy campaigns in elections; by building sites for supporters and to publish and distribute news through them [11].

SNSS are considered appropriate environments for civic and political participation, it allows politicians to speak of their political views and exchange them with others, as well as crowding and political attracting via e-mails and electronic invitations that carry political implications, SNSS contribute in political awareness between people and provide knowledge and information about the political process and increase civic and political participation, develop political self-skills, and keep in connect with political issues of their countries [12]. They play a vital role in developing electronic education, it increase students communication after school, break time barrier outside school, eliminate formalities inside educational institutions, increases communicating with teachers individually and in groups, gives students the ability to communicate free of anxiety, shyness and to express opinions [13].

SNSS became means of marketing, promotions and providing commercial services. The marketing process went to interaction between consumers and marketing enterprises. Assessments and notes provided by consumers are considered valuable information for the enterprise and are required to develop products [14].

\subsection{Theoretical Framework}

Over the past few years, programs allowed interaction via virtual social networks. Most of the researches have 
discussed cultural and behavioral impact on SNSS in western and eastern societies, but there is paucity in the literature of peoples engagement in SNSS on their values assimilation. Value concept was defined as "a set of cognitive, emotional, and behavioral well-established perceptions and beliefs freely chosen by the individual following thinking, mediation, and deep belief. These values form the criteria throw which we judge good or bad, accept or refuse things. Organized, steady and proudly repeated behavior emerges [2].

Value were defined as "a set of principles, rules, norms, ideals, laws and standards derived from education to adjust individuals and societies behaviors and to judge their ideas, behaviors and emotions seeking the pleasure of Allah” [15].

\subsection{Procedural Definitions}

For the purpose of the study the following definitions were used:

Assimilation, is the assessment level that reflects the degree of student's assimilation of the values. It is measured by student's scores on the value assimilation test.

Social Networks, are web-based services that allow individuals to make public profiles within a bounded system, choose other users with whom to share a connection and get acquainted, and view and pass through list of connections and those made by others within the system [16], such as Facebook, Twitter, WhatsApp and YouTube.

Values, are a set of standards and principals that guides and controls individuals behavior. By this set actions of individuals are rendered right or wrong. They are also the reference in decision making that achieves moral and material gains for individuals and communities. In this study they are social, moral and teaching and learning values.

\subsection{Importance of the Study}

Social networks are drawing the attention of researchers all around the globe. The author became interested to conduct a study to explore the importance of social networks role in values assimilation, since a gap exists in this field among university students of Arabic cultures. The importance is obvious in the social networks role in forming tendencies, values, and in changing dominant concepts. Social networks may be considered means of guiding social and political movements in the society. Nowadays we desperately need to maintain stability and cohesion and face changes around us through consolidating original values and develop them among our children.

\section{Study Questions}

1) What is the degree of Qassim university student's assimilation of values from their point of view?

2) Are there significant differences at $(\alpha=0.05$ ) between means of students assimilation attributed to; cumulative average, the educational level of the father, the educational level of the mother and the family monthly income?

3) What is the role of the social networks in Qassim university student's assimilation of values from their point of view?

4) Are there statistical differences at $(\alpha=0.05)$ between means of the social networks role in the Qassim university students assimilation of values attributed to gender, the number of friends on the sites?

\section{Literature Review}

Studies examining SNSS role in value assimilation, those relevant to the current study are summarized following:

Social values of satellite channels were examined [17]. There was a positive effect of watching satellite channels in promoting values such as helping family members, love of the family, friends status and helping others. Channels did not affect selfishness and inconsideration of others feelings.

The degree of basic school student's assimilation of social values in Amman/Jordan and the factors affecting them were examined [18]. It was found that the students assimilated values; honesty scored first. Statistical differences attributed to gender in favor of females, to place of residence in favor of city dwellers, to level of parents education in favor of higher levels of education. 
A study in Yemen [19] examined the state of using the internet and SNSS in the educational process and scientific research. The author interviewed participants and involved them in a test. It was found that teachers did not use internet and SNSS in teaching and scientific research. It was also found that main obstacles for not using it was the lack of funding, lack of connections between teachers and students, lack of subscriptions in digital libraries and periodicals, and weak employment of websites in the educational process.

Satellite channels effect on social values among high school students at Riyadh province were studied [20]. A major effect was found of satellite channels on social values such as contribution in emergencies, social services, show and develop cooperation and collaboration concepts. While the values of voluntary work and provide free services scored last. It was also found that satellite channels do not contribute in solving family problems.

The role of public and private Kuwaiti satellite channels in promoting citizenship values among Kuwaiti youth were studied [21]. A random sample of the University of Kuwait and the Gulf University for Science and Technology students participated. Statistical differences attributed to; university type and educational level were not found.

The student's moral values assimilation degree at Hail province/Saudi Arabia was examined [22]. The degree was found high. Statistical differences attributed to the study major and cumulative average were not found. Differences attributed to the parental educational level were found in favor of higher educational levels parents.

The educational role of the media in construction and assimilation of social values among young Emiratis was examined [1]. Television was found the most effective media in constructing the Emirati character and in providing values of the society, followed by internet. More than half of the participants agreed that media has a significant role in entrenching the values of citizenship and loyalty to highlight the civilized Emiratis.

The impact of SNSS in the social values of Jordan Universities students was identified [23]. An effect was found of SNSS on values in favor of social values, but the political values impact was averaged. Statistically significant differences attributed to students major were found in favor of the humanity colleges.

An overview of the previous literature yielded:

The variables varied for instance, [17]; [18]; [20]; [1] and [23] identified social values, while [21] studied citizenship, [19] examined learning and teaching, [22] examined moral values. Some studies studied satellite channels roles. But [19] and [23] studied the SNSS roles. Based on the previous literature the current study differentiated from other studies in tackling the role of SNSS in value assimilation in different domains such as; education and learning, social values and moral values, while other studies settled with one domain such as social values or citizenship. It also differs by including the variable of family monthly income.

\section{Methods}

\subsection{Population}

Participants from Qassim University/the College of Arts and Sciences/Al-Rass governorate (No. 9347), of them (3762) were male students and (5585) were female students. The sample was determined randomly, it included (370) male and female students. Table 1 and Table 2 illustrate repetitions and percentages according to the study variables.

\subsection{Measures}

Two instruments were employed in the study.

\begin{tabular}{cccc} 
Table 1. Repetitions and percentages according to the variables. \\
\hline Variables & Categories & Repetition & Percentage \\
\hline Gender & Male & 176 & 47.6 \\
& Female & 194 & 52.4 \\
Friends No. & Less than 15 & 72 & 19.5 \\
& 16 - 30 & 113 & 30.5 \\
& 31 and above & 185 & 50 \\
& Total & 370 & 100 \\
\hline
\end{tabular}


Table 2. Repetitions and percentages according to the variables.

\begin{tabular}{cccc}
\hline Variables & Categories & Repetition & Percentage \\
\hline Average & Excellent & 82 & 22.2 \\
& Very good & 121 & 32.7 \\
& Good & 167 & 45.1 \\
Family income & Less than 5000 Riyals & 81 & 21.9 \\
& 5000 - 10,000 Riyals & 183 & 49.5 \\
Fathers' education & More than 10,000 Riyals & 106 & 28.6 \\
& Graduate & 55 & 14.9 \\
& Postgraduate & 118 & 31.9 \\
Mothers' education & High school or less & 197 & 53.2 \\
& Graduate & 44 & 11.9 \\
& Postgraduate & 119 & 32.2 \\
& High school or less & 207 & 55.9 \\
& Total & 370 & 100 \\
\hline
\end{tabular}

“The degree of student's assimilation of values” and "SNSS role in students' values assimilation” tests were constructed as follows;

1) Reviewing previous literature;

2) Discussing the study problem with other teachers at the faculty to benefit from their expertise in determining the instruments;

3) Constructing the tests by consulting similar ones;

4) Validating the tests by consulting competent professors, reliability is insured by test-retest a survey sample (No. 40) applying an interval of two weeks. Then Pearson correlation was calculated. Internal consistency is calculated for reliability as illustrated in Table 3 and Table 4.

\subsection{Instrument Validity}

Construct validity of the test in terms of each items correlation with the dimension and with the overall tests was established. Internal consistency of the items was established by calculating correlations between the domains and overall test. Content validity was established by competent professor's review of the items, they provided comments and the author considered these comments.

\subsection{Study Variables}

Independent variables. Qassim postgraduates gender (male or female); the number of friends on SNSS (less than 15, 16 - 30 or 31 and above); family monthly income (Less than 5000 Riyals, 5000 - 10000 or More than 10,000 Riyals); average (Excellent, Very Good or Good); Fathers’ Education (Graduate, Postgraduate or High school or less) and Mothers’ Education (Graduate, Postgraduate or High school or less).

Dependent variable. Qassim postgraduate's responses on both tests.

Based on the variables and aims of the study, the author calculated means and standard deviations of the variables; Pearson correlation coefficient to clarify the correlation between the variables; reliability and validity of the tests and two-way ANOVA analysis.

\section{Results}

To answer the first question "What is the degree of Qassim university students assimilation of values from their point of view?” means and standard deviations were calculated as illustrated in Table 5.

It is observed in Table 5 that means range (3.22 - 3.69), where moral values score was the highest (3.89) and social values score was the least (3.22), overall test mean score (3.53). 
Table 3. Cronbach internal consistency coefficient and retest reliability based on test dimension and overall test.

\begin{tabular}{ccc}
\hline Dimension & Retest reliability & Internal consistency coefficient \\
\hline Teaching and learning values & 0.94 & 0.84 \\
Social values & 0.91 & 0.83 \\
Moral values & 0.89 & 0.90 \\
Overall test & 0.92 & 0.93 \\
\hline
\end{tabular}

Table 4. Cronbach internal consistency coefficient and retest reliability based on test dimension and overall test.

\begin{tabular}{ccc}
\hline Dimension & Retest reliability & Internal consistency coefficient \\
\hline Teaching and learning values & 0.91 & 0.88 \\
Social values & 0.89 & 0.88 \\
Moral values & 0.93 & 0.85 \\
Overall test & 0.90 & 0.94 \\
\hline
\end{tabular}

Table 5. Means and standard deviations of Qassim postgraduate's assimilation of values from their point of view in means descendant order.

\begin{tabular}{cccccc}
\hline Item order & Item N. & Dimension & Mean & Standard deviation & Level \\
\hline 1 & 3 & Moral values & 3.69 & 0.591 \\
2 & 1 & Teaching and learning values & 3.60 & 0.610 \\
3 & 2 & Social values & 3.22 & 0.666 \\
& & Overall degree & 3.53 & 0.576 \\
\hline
\end{tabular}

To answer the second question "Are there significant differences at $(\alpha=0.05)$ between means of students assimilation attributed to; cumulative average, the educational level of the father, the educational level of the mother and the family monthly income?" means and standard deviations were calculated as illustrated in Table 6 .

In Table 6 we notice apparent variation in means and standard deviations of the student's assimilation of values according to average, family monthly income, fathers' education and mothers' education. To show significance statistical functions between the means MANOVA analysis is conducted for each variable as shown in Table 7, and for overall test as shown in Table 8.

In Table 7 it is observed that there are no statistical differences at $(\alpha=0.05)$ attributed to all the dimensions, but statistical differences at $(\alpha=0.05)$ attributed to the effect of family monthly income are found. To show the statistical significance functions between the means Scheffe test is implemented as shown in Table 9 .

Statistical differences are found at $(\alpha=0.05)$ attributed to fathers' education in all the dimensions. To show the statistical significance functions between the means Scheffe test is implemented as shown in Table 10.

Statistical differences are also seen at $(\alpha=0.05)$ attributed to mothers' education in all the dimensions. To show the statistical significance functions between the means Scheffe test is implemented as shown in Table 11.

As observed in Table 8 no statistical differences at $(\alpha=0.05)$ attributed to the effect of the average are found $F$ value score (0.471) and a significance of (0.659). Statistical differences at $(\alpha=0.05)$ attributed to the effect of the family monthly income are also found, $F$ value score (9.297) and a significance of (0.000). To show the statistical significance functions between the means Scheffe test is implemented as shown in Table 9.

As observed in Table 9 significant statistical differences at $(\alpha=0.05)$ are found in the categories of Less than 5000 Riyals and in 5000 - 10,000 Riyals in favor of the second in "Teaching and Learning Values" and "Moral Values" dimensions.

Significant statistical differences at $(\alpha=0.05)$ are found in the categories of Less than 5000 Riyals and in 5000 - 10,000 Riyals in favor of the second in "Teaching and Learning Values" and "Moral Values" dimensions. 
Table 6. Means and standard deviations of Qassim postgraduates assimilation of values based on their average, family monthly income, fathers' education and mothers' education.

\begin{tabular}{|c|c|c|c|c|c|c|}
\hline & & & Teaching and learning values & Social values & Moral values & $\begin{array}{l}\text { Overall } \\
\text { degree }\end{array}$ \\
\hline \multirow[t]{6}{*}{ Average } & \multirow[t]{2}{*}{ Excellent } & M. & 3.64 & 3.32 & 3.72 & 3.58 \\
\hline & & $\mathrm{SD}$. & 0.666 & 0.707 & 0.565 & 0.604 \\
\hline & \multirow[t]{2}{*}{ Very Good } & M. & 3.58 & 3.24 & 3.69 & 3.53 \\
\hline & & $\mathrm{SD}$ & 0.554 & 0.605 & 0.577 & 0.523 \\
\hline & \multirow[t]{2}{*}{ Good } & M. & 3.59 & 3.17 & 3.67 & 3.50 \\
\hline & & SD. & 0.623 & 0.685 & 0.616 & 0.600 \\
\hline \multirow{6}{*}{$\begin{array}{l}\text { Family } \\
\text { income }\end{array}$} & \multirow[t]{2}{*}{ Less than 5000 Riyals } & M. & 3.42 & 3.04 & 3.55 & 3.37 \\
\hline & & SD. & 0.614 & 0.647 & 0.658 & 0.600 \\
\hline & \multirow[t]{2}{*}{5000 - 10,000 Riyals } & M. & 3.70 & 3.33 & 3.8 & 3.64 \\
\hline & & SD. & 0.603 & 0.684 & 0.505 & 0.546 \\
\hline & \multirow[t]{2}{*}{ More than 10,000 Riyals } & M. & 3.55 & 3.18 & 3.6 & 3.47 \\
\hline & & SD. & 0.586 & 0.615 & 0.642 & 0.574 \\
\hline \multirow{6}{*}{$\begin{array}{l}\text { Fathers' } \\
\text { education }\end{array}$} & \multirow[t]{2}{*}{ Graduate } & M. & 3.86 & 3.50 & 3.96 & 3.8 \\
\hline & & SD. & 0.634 & 0.738 & 0.506 & 0.579 \\
\hline & \multirow[t]{2}{*}{ Postgraduate } & M. & 3.55 & 3.20 & 3.63 & 3.49 \\
\hline & & $\mathrm{SD}$ & 0.645 & 0.711 & 0.649 & 0.615 \\
\hline & \multirow[t]{2}{*}{ High school or less } & M. & 3.55 & 3.16 & 3.65 & 3.48 \\
\hline & & $\mathrm{SD}$ & 0.565 & 0.597 & 0.559 & 0.532 \\
\hline \multirow{6}{*}{$\begin{array}{l}\text { Mothers' } \\
\text { education }\end{array}$} & \multirow[t]{2}{*}{ Graduate } & M. & 3.87 & 3.62 & 3.87 & 3.8 \\
\hline & & SD. & 0.689 & 0.798 & 0.570 & 0.633 \\
\hline & \multirow[t]{2}{*}{ Postgraduate } & M. & 3.64 & 3.24 & 3.73 & 3.57 \\
\hline & & SD. & 0.599 & 0.681 & 0.595 & 0.575 \\
\hline & \multirow[t]{2}{*}{ High school or less } & M. & 3.51 & 3.13 & 3.63 & 3.45 \\
\hline & & $\mathrm{SD}$ & 0.581 & 0.593 & 0.585 & 0.546 \\
\hline
\end{tabular}

M: mean; SD: standard deviation.

Table 7. MANOVA analysis of average, family monthly income, fathers' education and mothers' education effect on the study dimensions.

\begin{tabular}{|c|c|c|c|c|c|c|}
\hline Source of variance & Dimension & $\begin{array}{l}\text { Sum of } \\
\text { squares }\end{array}$ & $\begin{array}{l}\text { Degree of } \\
\text { freedom }\end{array}$ & $\begin{array}{c}\text { Means } \\
\text { squared }\end{array}$ & Value F & Sig. \\
\hline Average & Teaching and learning values & 0.182 & 2 & 0.091 & 0.270 & 0.763 \\
\hline \multirow{2}{*}{ Wilks’ Lambda $=0.986 \mathrm{P}=0.526$} & Social values & 0.768 & 2 & 0.384 & 0.979 & 0.377 \\
\hline & Moral values & 0.144 & 2 & 0.072 & 0.224 & 0.799 \\
\hline Family monthly income & Teaching and learning values & 5.800 & 2 & 2.900 & 8.619 & 0.000 \\
\hline \multirow{2}{*}{ Wilks' Lambda $=0.943 \mathrm{P}=0.002$} & Social values & 6.145 & 2 & 3.072 & 7.827 & 0.000 \\
\hline & Moral values & 5.041 & 2 & 2.521 & 7.842 & 0.000 \\
\hline Fathers' education & Teaching and learning values & 5.231 & 2 & 2.615 & 7.773 & 0.000 \\
\hline \multirow{2}{*}{ Wilks’ Lambda $=0.946 \mathrm{P}=0.003$} & Social values & 6.410 & 2 & 3.205 & 8.164 & 0.000 \\
\hline & Moral values & 5.374 & 2 & 2.687 & 8.360 & 0.000 \\
\hline Mothers' education & Teaching and learning values & 5.868 & 2 & 2.934 & 8.721 & 0.000 \\
\hline \multirow{2}{*}{ Wilks' Lambda $=0.930 \mathrm{P}=0.000$} & Social values & 9.648 & 2 & 4.824 & 12.289 & 0.000 \\
\hline & Moral values & 3.184 & 2 & 1.592 & 4.953 & 0.008 \\
\hline \multirow[t]{3}{*}{ Error } & Teaching and learning values & 121.464 & 361 & 0.336 & & \\
\hline & Social values & 141.704 & 361 & 0.393 & & \\
\hline & Moral values & 116.034 & 361 & 0.321 & & \\
\hline \multirow[t]{3}{*}{ Overall } & Teaching and learning values & 137.325 & 369 & & & \\
\hline & Social values & 163.567 & 369 & & & \\
\hline & Moral values & 128.893 & 369 & & & \\
\hline
\end{tabular}


Table 8. MANOVA analysis of average, family monthly income, fathers' education and mothers' education effect on students assimilation of values.

\begin{tabular}{cccccc}
\hline Source of variance & Sum of squares & Degree of freedom & Means squared & Value F & Sig. \\
\hline Average & 0.247 & 2 & 0.123 & 0.417 & 0.659 \\
Family monthly income & 5.499 & 2 & 2.750 & 9.297 & 0.000 \\
Fathers' education & 5.567 & 2 & 2.784 & 9.412 & 0.000 \\
Mothers education & 5.458 & 2 & 2.729 & 9.227 & 0.000 \\
Error & 106.764 & 361 & 0.296 & & \\
Overall & 122.458 & 369 & & & \\
\hline
\end{tabular}

Table 9. Scheffe test of the family monthly income.

\begin{tabular}{|c|c|c|c|c|c|}
\hline & & M. & $\begin{array}{l}\text { Less than } 5000 \\
\text { Riyals }\end{array}$ & $\begin{array}{l}5000 \text { - 10,000 } \\
\text { Riyals }\end{array}$ & $\begin{array}{c}\text { More than } 10,000 \\
\text { Riyals }\end{array}$ \\
\hline \multirow{3}{*}{$\begin{array}{l}\text { Teaching and } \\
\text { learning values }\end{array}$} & Less than 5000 Riyals & 3.42 & & & \\
\hline & 5000 - 10,000 Riyals & 3.70 & $0.28^{*}$ & & \\
\hline & More than 10,000 Riyals & 3.55 & 0.13 & 0.15 & \\
\hline \multirow{3}{*}{ Social values } & Less than 5000 Riyals & 3.04 & & & \\
\hline & 5000 - 10,000 Riyals & 3.33 & $0.30^{*}$ & & \\
\hline & More than 10,000 Riyals & 3.18 & 0.14 & 0.16 & \\
\hline \multirow{3}{*}{ Moral values } & Less than 5000 Riyals & 3.55 & & & \\
\hline & 5000 - 10,000 Riyals & 3.80 & $0.25^{*}$ & & \\
\hline & More than 10,000 Riyals & 3.60 & 0.05 & $0.20^{*}$ & \\
\hline \multirow{3}{*}{ Overall } & Less than 5000 Riyals & 3.37 & & & \\
\hline & 5000 - 10,000 Riyals & 3.64 & $0.27^{*}$ & & \\
\hline & More than 10,000 Riyals & 3.47 & 0.10 & $0.17^{*}$ & \\
\hline
\end{tabular}

${ }^{*}$ Functional at $(\alpha=0.05)$.

Table 10. Scheffe test of the fathers' education effect.

\begin{tabular}{|c|c|c|c|c|c|}
\hline & & M. & Graduate & Postgraduate & High school or less \\
\hline \multirow[t]{3}{*}{ Teaching and learning values } & Graduate & 3.86 & & & \\
\hline & Postgraduate & 3.55 & $0.31^{*}$ & & \\
\hline & High school or less & 3.55 & $0.31^{*}$ & 0.00 & \\
\hline \multirow[t]{3}{*}{ Social values } & Graduate & 3.50 & & & \\
\hline & Postgraduate & 3.20 & $0.30^{*}$ & & \\
\hline & High school or less & 3.16 & $0.34^{*}$ & 0.04 & \\
\hline \multirow[t]{4}{*}{ Moral values } & Graduate & 3.96 & & & \\
\hline & Postgraduate & 3.63 & $0.32^{*}$ & & \\
\hline & High school or less & 3.65 & $0.31^{*}$ & -0.01 & \\
\hline & Graduate & 3.80 & & & \\
\hline \multirow[t]{2}{*}{ Overall } & Postgraduate & 3.49 & $0.31^{*}$ & & \\
\hline & High school or less & 3.48 & $0.32^{*}$ & 0.01 & \\
\hline
\end{tabular}

*Functional at $(\alpha=0.05)$. 
Table 11. Scheffe test of the mothers' education effect.

\begin{tabular}{|c|c|c|c|c|c|}
\hline & & M. & Graduate & Postgraduate & High school or less \\
\hline \multirow[t]{3}{*}{ Teaching and learning values } & Graduate & 3.87 & & & \\
\hline & Postgraduate & 3.64 & 0.23 & & \\
\hline & High school or less & 3.51 & $0.36^{*}$ & 0.13 & \\
\hline \multirow[t]{3}{*}{ Social values } & Graduate & 3.62 & & & \\
\hline & Postgraduate & 3.24 & $0.38^{*}$ & & \\
\hline & High school or less & 3.13 & $0.49^{*}$ & 0.12 & \\
\hline \multirow[t]{3}{*}{ Moral values } & Graduate & 3.87 & & & \\
\hline & Postgraduate & 3.73 & 0.14 & & \\
\hline & High school or less & 3.63 & $0.25^{*}$ & 0.11 & \\
\hline \multirow[t]{3}{*}{ Overall } & Graduate & 3.80 & & & \\
\hline & Postgraduate & 3.57 & 0.24 & & \\
\hline & High school or less & 3.45 & $0.35^{*}$ & 0.12 & \\
\hline
\end{tabular}

${ }^{*}$ Functional at $(\alpha=0.05)$.

Statistical significant differences are observed in Table 10 at $(\alpha=0.05)$ between the graduate category and both of postgraduate and high school or less in favor of the graduates in all the dimensions and overall test.

Statistical significant differences are observed in Table 11 at $(\alpha=0.05)$ between the graduate category and both of postgraduate and high school or less in favor of the graduates in all the dimensions and overall test. Statistical significant differences are also observed at $(\alpha=0.05)$ between the graduate category and both of postgraduate and high school or less in favor of the graduates in social value.

To answer the third question "What is the role of the social networks in Qassim university student's assimilation of values from their point of view?” means and standard deviations of the SNSS roles in Qassim student's assimilation of values are calculated as observed in Table 12.

Table 12 illustrates that means ranged between (3.21 - 3.89), the "teaching and learning values" scored the highest (M. = 3.89), the last was "social values" scoring $\left(\mathrm{M}_{.}=3.21\right)$, the overall score was $(\mathrm{M} .=3.63)$.

To answer the fourth question "Are there statistical differences at $(\alpha=0.05)$ between means of the social networks role in the Qassim university students assimilation of values attributed to gender, the number of friends on the sites?" means and standard deviations of the SNSS roles in Qassim students assimilation of values based on gender and the number of friends are calculated as observed in Table 13.

In Table 13 we notice apparent variation in means and standard deviations of the student's responses according to according to gender and the number of friends. Means ranged between (3.06 - 3.98), and to show the statistical functions between the means 2-way MANOVA analysis is conducted for the dimensions as shown in Table 14, and a 2-way ANOVA for overall test as shown in Table 15.

As observed in Table 15 no statistical differences at $(\alpha=0.05)$ attributed to the effect of the gender are found, $F$ score (1.242) and a significance score (0.266) in all dimensions. Statistical differences at $(\alpha=0.05)$ attributed to the effect of the number of friends are found, $F$ score (5.289) and a significance score (5.289). To show the statistical significance functions between the means Scheffe test is implemented as shown in Table 16.

From Table 15 it is observed that there are statistical differences at $(\alpha=0.05)$ attributed to gender in all the dimensions. To show the statistical significance functions between the means Scheffe test is implemented as shown in Table 10.

As observed in Table 16 statistical differences at $(\alpha=0.05)$ attributed to the effect of the number of friends are found between the categories of "less than 15" and " 31 and above", in favor of "31 and above" in the dimensions of "Teaching and Learning Values" and "Moral Values".

Statistical differences at $(\alpha=0.05)$ attributed to the effect of the number of friends are found between the categories of "31 and above" with "Less than 15" and " 16 - 30", in favor of "31 and above" in the dimensions of "Social Values" and overall degree. 
Table 12. Means and standard deviations of SNSS roles in Qassim student's assimilation of values from their point of view in means descendant order.

\begin{tabular}{|c|c|c|c|c|c|}
\hline Item order & Item $\mathrm{N}$. & Dimension & Mean & Standard deviation & Level \\
\hline 1 & 1 & Teaching and learning values & 3.89 & 0.605 & \\
\hline 2 & 3 & Moral values & 3.76 & 0.526 & \\
\hline \multirow[t]{2}{*}{3} & 2 & Social values & 3.21 & 0.726 & \\
\hline & & Overall degree & 3.63 & 0.551 & \\
\hline
\end{tabular}

Table 13. Means and standard deviations of Qassim students responses according to gender and number of friends.

\begin{tabular}{|c|c|c|c|c|c|c|}
\hline & & & Teaching and learning values & Social values & Moral values & Overall degree \\
\hline \multirow{4}{*}{ Gender } & Male & M. & 3.95 & 3.95 & 3.81 & 3.68 \\
\hline & & SD. & 0.597 & 0.597 & 0.557 & 0.530 \\
\hline & Female & M. & 3.84 & 3.84 & 3.72 & 3.58 \\
\hline & & $\mathrm{SD}$ & 0.610 & 0.610 & 0.494 & 0.566 \\
\hline \multirow{6}{*}{ Friends No. } & Less than 15 & M. & 3.76 & 3.76 & 3.65 & 3.49 \\
\hline & & SD. & 0.642 & 0.642 & 0.562 & 0.537 \\
\hline & $16-30$ & M. & 3.83 & 3.83 & 3.71 & 3.55 \\
\hline & & SD. & 0.566 & 0.566 & 0.488 & 0.48 \\
\hline & 31 and above & M. & 3.98 & 3.98 & 3.84 & 3.72 \\
\hline & & SD. & 0.603 & 0.603 & 0.525 & 0.580 \\
\hline
\end{tabular}

Table 14. 2-way MANOVA analysis of the gender and the friends N. effect on the study dimensions.

\begin{tabular}{|c|c|c|c|c|c|c|}
\hline Source of variance & Dimension & $\begin{array}{l}\text { Sum of } \\
\text { squares }\end{array}$ & $\begin{array}{l}\text { Degree of } \\
\text { freedom }\end{array}$ & $\begin{array}{l}\text { Means } \\
\text { squared }\end{array}$ & Value F & Sig. \\
\hline Gender & Teaching and learning values & 0.499 & 1 & 0.499 & 1.389 & 0.239 \\
\hline \multirow[t]{2}{*}{ Hottelling $=0.004 \mathrm{P}=0.656$} & Social values & 0.200 & 1 & 0.200 & 0.390 & 0.533 \\
\hline & Moral values & 0.427 & 1 & 0.427 & 1.572 & 0.211 \\
\hline Friends No. & Teaching and learning values & 2.571 & 2 & 1.286 & 3.575 & 0.029 \\
\hline \multirow[t]{2}{*}{ Wilks' Lambda $=0.943 \mathrm{P}=0.002$} & Social values & 5.644 & 2 & 2.822 & 5.502 & 0.004 \\
\hline & Moral values & 2.036 & 2 & 1.018 & 3.751 & 0.024 \\
\hline \multirow[t]{3}{*}{ Error } & Teaching and learning values & 131.638 & 366 & 0.360 & & \\
\hline & Social values & 187.736 & 366 & 0.513 & & \\
\hline & Moral values & 99.315 & 366 & 0.271 & & \\
\hline \multirow[t]{3}{*}{ Overall } & Teaching and learning values & 135.261 & 369 & & & \\
\hline & Social values & 194.238 & 369 & & & \\
\hline & Moral values & 102.233 & 369 & & & \\
\hline
\end{tabular}

\section{Discussion}

In the first question "What is the degree of Qassim university student's assimilation of values from their point of view?” student's responses to their assimilation of values overall test were calculated by means and standard deviations. The mean from their point of view was average, overall test scored (3.35), other means ranged between (3.22 - 3.69). This result indicates the necessity to focus on acquiring students with values and enhancing 
Table 15. 2-way ANOVA analysis of the gender and the friends N. effect on the study dimensions.

\begin{tabular}{|c|c|c|c|c|c|}
\hline Source of variance & Sum of squares & Degree of freedom & Means squared & Value F & Sig. \\
\hline Gender & 0.366 & 1 & 0.366 & 0.266 & 0.266 \\
\hline N. of friends & 3.117 & 2 & 1.558 & 0.005 & 0.005 \\
\hline Error & 107.845 & 366 & 0.295 & & \\
\hline Overall & 111.884 & 369 & & & \\
\hline
\end{tabular}

Table 16. Scheffe test of the number of friends effect.

\begin{tabular}{ccccc}
\hline & M. & Less than 15 & $16-30$ & 31 and above \\
\hline Teaching and learning values & Less than 15 & 3.76 & & \\
& $16-30$ & 3.83 & 0.08 & 0.15 \\
Social values & 31 and above & 3.98 & $0.22^{*}$ & \\
& Less than 15 & 3.06 & 0.04 & $0.24^{*}$ \\
Moral values & $16-30$ & 3.09 & $0.28^{*}$ & \\
& 31 and above & 3.34 & 0.06 & \\
Less than 15 & 3.65 & 3.71 & $0.20^{*}$ & \\
Overall & 16 - 30 & 3.84 & 0.06 & $0.17^{*}$ \\
\hline
\end{tabular}

it. The author attributes this result to the many reasons that affect their assimilation of values, such as technology and SNSS that are misused. The result agrees with [18] and disagrees with [22] where the degree was high.

As for the second question of "Are there significant differences at $(\alpha=0.05)$ between means of students assimilation attributed to; cumulative average, the educational level of the father, the educational level of the mother and the family monthly income?" results revealed that the effect of the student average was not statistically significant at $(\alpha=0.05)$ in all the dimensions. This result is attributed to the fact that the average is not the real indicator of student's assimilation of values. Modern education focus on the fact that says "average is not the real indicator of individuals thought, tendencies or behavior. This result agrees with the study of [22].

Insignificant differences at $(\alpha=0.05)$ attributed to the effect of family monthly income were found in all the dimensions, differences were in favor of the category of (5000 - 10,000 Riyals) in the dimensions of "Teaching and Learning Values" and "Social Values". This result is attributed to average family income tendency to use balanced parental styles, do not over pamper in comparison with high income families, or the strictness exerted by low income families.

Differences were found at $(\alpha=0.05)$ attributed to; the mothers' education in favor of postgraduates in the dimension of social values; to the fathers' education in favor of postgraduates in all the dimensions. This result is attributed to parents' high level of education reflection on parenting children. Parents high educational levels have flexible mature thinking, a holistic perspective in dealing with their children, they tend to acquire their children distinct personalities, provide them with positive values comparing with parents of low educational levels. This result agrees with the study of [22] and [18].

The third question "What is the role of the social networks in Qassim university student's assimilation of values from their point of view?" student's responses about the role of SNSS in their assimilation of values overall test were calculated by means and standard deviations. The mean scores was average, overall test scored (3.63), other means ranged between (3.21 - 3.89). This result refers to the importance of this study. The author attributes this result to the important role of SNSS in student's assimilation of values and in affecting these values. The result agrees with the [1]; [17]; [19]-[21] and [23]. 
The dimension of "Teaching and Learning Values" scores was the highest $(M=3.89)$, while "Social Values" scores were the least $(\mathrm{M}=3.21)$. This result is attributed to the important role of these SNSS in developing the value of teaching and learning especially at the university, where students in this stage spend time in studying, their contact with SNSS is for learning purposes and is greater compared with other stages. But this result does not mean that other dimensions of "Social and Moral values" do not have an effect. This study disagrees with the study of [23].

The fourth question "Are there statistical differences at $(\alpha=0.05)$ between means of the social networks role in the Qassim university students assimilation of values attributed to gender, the number of friends on the sites?” analysis found no statistical differences at $(\alpha=0.05)$ attributed to gender in all the dimensions. This result is attributed to the SNSS effect on both genders. This result agrees with the study of [1] and [21], but disagrees with the study of [23].

Statistical differences at $(\alpha=0.05)$ attributed to the number of friends in all the dimensions and in favor of the category "More than 31 friend" were found in social values dimension and in the overall degree. This result is attributed to the increase in the number of friends, the increase increases expertise and knowledge shared between friends by images, articles and videos. This in turn increases being affected by each other, especially in the social relationships dimension. This result agrees with the study of [23].

\subsection{Implications}

Based on the results of this study educators must combine efforts in order to raise students consciousness about the positives and negatives of SNSS, because they are considered a two edged weapon. Moral and behavioral threats are found and these might destroy good values. Legislations of using SNSS are required and should be implemented on users. Purposeful SNSS construction under the supervision of scholars and thinkers who adopt youth issues of different social, cultural, political and economic issues to share knowledge and interests is needed. Programming experts are recommended to provide suitable security tools constructed based on cultures values. Urge students to use SNSS positively by holding seminars, lectures and other techniques to build their self-awareness. Other organizations than universities are recommended to conduct similar studies on different age groups.

\subsection{Limitations of the Study}

The study is limited by its sample; hence it only may be generalized on similar samples; the age group taken in the study is 18 - 22 years which represents only one age group; some of the SNSS were taken for study but not all of them; students provided their view points of assimilating values; other categories such as teachers and parents may be considered. These are considered the limitations of the study.

\section{References}

[1] Bader, A. (2013) The Educational Role of the Media in Establishing Society Values among Emirati Youth. Jerash Journal of Research and Studies, 149.

[2] Jallad, M.Z. (2007) Values Learning and Teaching, a Theoretical Conceptualization of Value Teaching Strategies. Dar Al-Maserah, Amman.

[3] Mohammad, W. and Al-Helo, A. (1999) Kindergarten Role in Acquiring Children Social Values. Paper Submitted to the Conference of "Values and Education in a Changing World", Yarmouk University, Irbid.

[4] Njadat, A.M. (1999) Holy Quran and Sunnah Styles in Teaching Islamic Values. Paper Submitted to the Conference of "Values and Education in a Changing World", Yarmouk University, Irbid.

[5] Corich, S.K. and Hunt, L. (2004) Assessing Discussion Forum Participation: In Search of Quality. ITDL Journal, 1, 33.

[6] Al-Alami, L. (2011) Membership at SNSS and Its Effect in Enhancing the Political Awareness among Al-Najah University Students. Al-Najah National University, Palestine.

[7] Kim, W., Jeong, O.-R. and Lee, S.-W. (2010) On Social Web Sites. Information System, 35, 215-236. http://dx.doi.org/10.1016/j.is.2009.08.003

[8] Al-Arfaj, N. (2012) Using SNSS and Is a Sophisticated Cost of Dialogue. Foundation of Civilized Communication and Dialogue, Al-Ahsa.

[9] Grimmelmann, J. (2009) Saving Face Book. Iowa Law Review, 94, 1137-1206. 
[10] Grabner-Kräuter, S. (2010) Web 2.0 Social Networks: The Role of Trust. Journal of Business Ethics, 90, 505-525. http://dx.doi.org/10.1007/s10551-010-0603-1

[11] Ali, L. (2008) Educating Facebook. Egyptian Group for Publishing and Distribution, Alexandria.

[12] Vitak, J., Zube, P., Smock, A., Carr, C., Ellison, N. and Lamp, C. (2011) It’s Complicated: Face Book User’s Political Participation in the 2008 Election. Cyber Psychology and Behavior and Social Networks, 14, 107-114. http://dx.doi.org/10.1089/cyber.2009.0226

[13] Klopfer, E, Osterweil, S., Groff, J. and Hass, J. (2009) Using the Technology of Today in the Classroom Today. Massachusetts Institute of Technology, Cambridge.

[14] Owen, R. and Humphrey, P. (2009) The Structure of Online Marketing Communication Channels. Journal of Marketing Research, 2, 1-10.

[15] Nejadat, A.M. (1999) Holy Quran and Sunnah Methods in Teaching and Learning of Islamic Values. Proceedings of Values and Education in a Changing World Conference, Yarmouk University, Irbid, 9-15.

[16] Boyd, D.M. and Ellison, N.B. (2007) Social Network Sites: Definition, History, and Scholarship. Journal of ComputerMediated Communication, 13, 210-230. http://www.danah.org/papers/JCMCIntro.pdf http://dx.doi.org/10.1111/j.1083-6101.2007.00393.x

[17] Al-Khadhab, H. (2005) Satellite Channels and Some Social Values. Unpublished Master Thesis, King Saud University, KSA.

[18] Sa'ed, B. (2009) The Degree of Amman Elementary Schools Students Assimilation of Social Values and Factors Affecting It. Unpublished Doctoral Thesis, Jordan University, Jordan.

[19] Ali, E. (2010) The Reality of Using the www in the Practical, Educational and Scientific Research Processes among Lecturers in Education Faculties at Yemini Universities. Unpublished Master Thesis, Umm Al Qura University, Mecca.

[20] Mobaraz, I. (2011) Satellite and Its Impact on Social Values among High School Students in Riyadh. Unpublished Master Thesis, University of Imam Muhammad Bin Saud, Riyadh.

[21] As-Sallal, B. (2012) The Kuwaiti Public and Private Satellite Channels Role in Enhancing Citizenship among Kuwaiti Youth. Middle East University, Kuwait.

[22] Ar-Robay'an, S. (2013) Degree of High School Students Assimilation of Values in Saudi Arabia, Hail Province. Unpublished Doctoral Thesis, Jordan University.

[23] Zain Al-Abidin, F. (2014) The Effect of SNSS in Social Values among Jordan Universities Students. Unpublished Doctoral Thesis, Jordan University. 